\title{
Neospora caninum antibodies in dairy cows and domestic dogs from Vojvodina, Serbia
}

\author{
Ljiljana Kuruca $^{1 *}$, Ljubica Spasojević-Kosić ${ }^{1}$, Stanislav $\operatorname{Simin}^{1}$, Milan Savović ${ }^{2}$, Saša Lauš ${ }^{3}$, \\ and Vesna Lalošević ${ }^{1}$ \\ 1 Faculty of Agriculture, University of Novi Sad, Trg Dositeja Obradovića 8, 21000 Novi Sad, Serbia \\ 2 PVP MSV Medicus D.O.O., Milice Stojadinović Srpkinje 1, 21209 Bukovac, Serbia \\ 3 Praxis Veterinaria D.O.O., 2. Oktobra 40, 26300 Vršac, Serbia
}

Received 28 June 2013, Accepted 5 October 2013, Published online 24 October 2013

\begin{abstract}
Neospora caninum, the causative agent of neosporosis, is a protozoan parasite responsible for high rate of abortion in cattle worldwide. In dogs, consequences of infection vary from severe neuromuscular disorders to asymptomatic infection and shedding of environmentally resistant oocysts. In this study, we determined the occurrence of $N$. caninum antibodies in dairy cattle and dogs in Vojvodina (Northern Province of Serbia) and possible risk factors. $N$. caninum antibodies were found in $15.4 \%$ (55/356, CI 95\%:12.0-19.6) of cows and $17.2 \%$ (17/99, CI 95\%: 10.8-26.2) of dogs. Cows from smallholdings showed significantly greater odds $(\mathrm{OR}=5.28$, CI 95\%: $2.0-13.6$, $p=0.0006$ ) of being seropositive in comparison to the farm cows. Epidemiological importance of results is discussed.
\end{abstract}

Key words: Anti-Neospora caninum antibodies, Dairy cows, Dogs, Risk factors, Vojvodina.

\begin{abstract}
Résumé - Anticorps contre Neospora caninum chez les vaches laitières et les chiens de Voïvodine, Serbie. Neospora caninum, l'agent qui cause la néosporose, est un parasite protozoaire responsable d'un taux élevé d'avortements dans le bétail à travers le monde. Chez les chiens, les conséquences de l'infection varient entre un trouble neuromusculaire sévère et une excrétion asymptomatique d'oocystes résistants dans l'environnement. L'objectif de cette étude était d'examiner le statut sérologique des vaches laitières et des chiens en Voïvodine (province du nord de la Serbie) et les facteurs de risque possibles. Des anticorps contre $N$. caninum ont été détectés dans 15,4\% (55/356, CI $95 \%: 12,0-19,6)$ des vaches et dans 17,2\% (17/99, CI $95 \%: 10,8-26,2)$ des chiens. Les vaches des petits propriétaires ont manifesté une probabilité significativement plus importante $(\mathrm{OR}=5,28$, CI $95 \%: 2,0-13,6, p=0,0006)$ d'être séropositives que les vaches de fermes. L'importance épidémiologique de ces résultats est discutée.
\end{abstract}

\section{Introduction}

The protozoan parasite Neospora caninum causes considerable economic losses to cattle industry worldwide [1].

One of the definitive hosts of $N$. caninum, which is responsible for shedding of environmentally resistant oocysts, is the domestic dog [6]. In dogs, neosporosis can cause severe clinical manifestations, including myositis-polyradiculoneuritis, encephalomyelitis and dermatitis [7, 12].

Worldwide reports of clinical and subclinical infections in all hosts were summarized by Dubey et al. [1] and Dubey and Schares [2], but there was no mention of neosporosis in Serbia. Recently, occurrence of $N$. caninum specific antibodies in both cattle and dogs has been confirmed in Serbia as well

\footnotetext{
*Corresponding author: pavicic.1jiljana@gmail.com
}

$[3,9,13,17]$ and published in local journals. The aim of this study was to investigate current serological status of dairy cattle and dogs in Vojvodina (Northern Province of Serbia), with regard to the possible risk factors.

\section{Material and methods}

\section{Studied area}

Vojvodina is a northern $\left(45^{\circ} 15^{\prime} \mathrm{N} 19^{\circ} 50^{\prime} \mathrm{E}\right)$ province of the Republic of Serbia which occupies $21,506 \mathrm{~km}^{2}$ of the state territory [5]. The major part of the province's territory consists of fertile plains with the Danube, Tisa and Sava rivers dividing it in to three regions: Bačka, Banat and Srem. The climate of Vojvodina is moderately continental, characterised by hot, dry summers, cold winters and relatively low rainfall. 


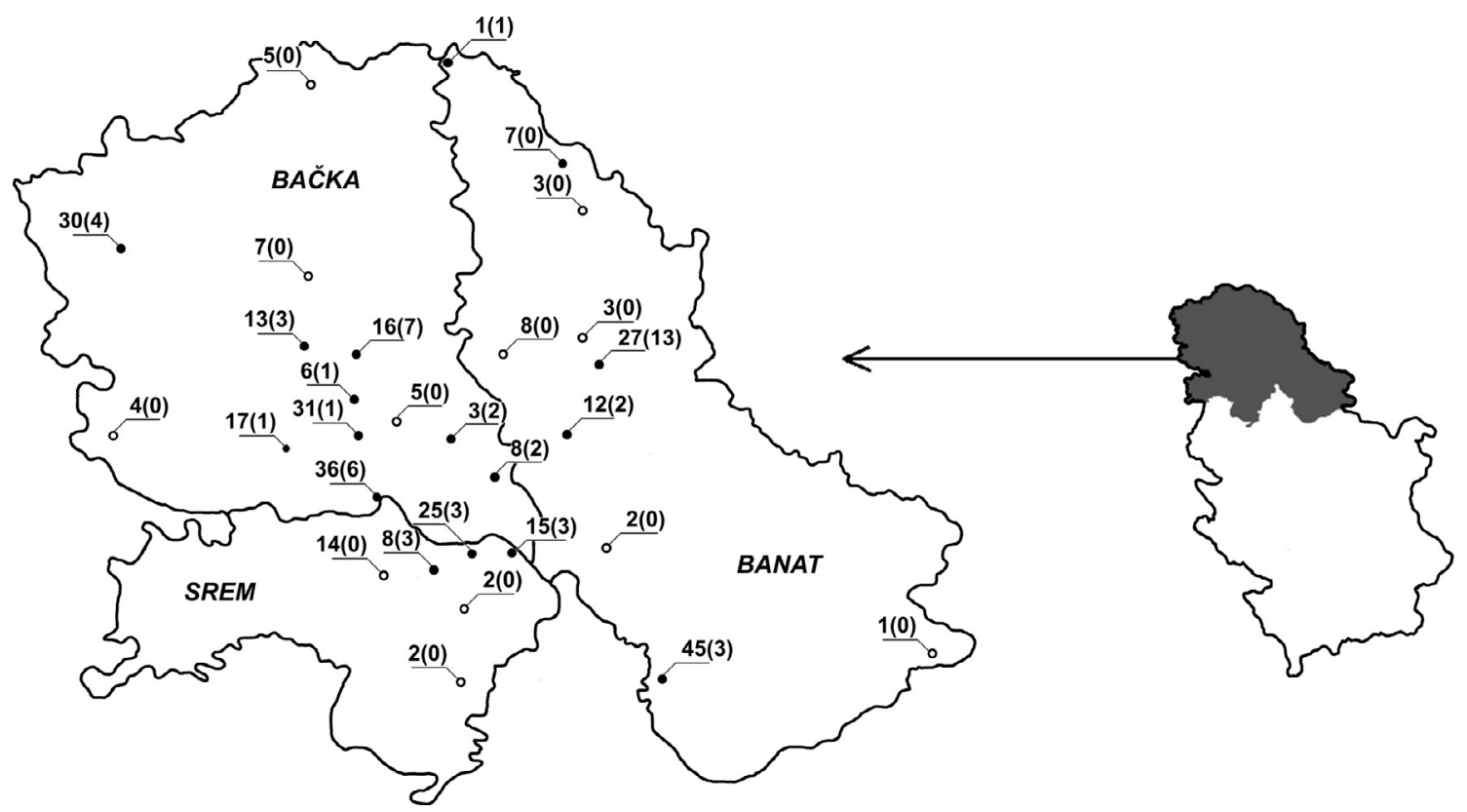

Figure 1. Dots on the map of Vojvodina represent localities where blood samples were taken from cows or, in the case of blood collected at the abattoir, places of cows' origin. Black dots refer to localities where seropositive cows were found, while white dots stand for localities where there were no positive samples. Figures represent the number of sampled cows from specific locality and number of positive ones (between parentheses).

\section{Animals and sample collection}

Blood samples were collected from 356 dairy cows from both commercial farms (109 cows) and smallholdings (247 cows) in Srem, Banat and Bačka region (Figure 1), during the 2009-2013 period. Samples from 271 cows were obtained on the farm by jugular venipuncture and 85 samples were collected at the abattoir. Among these were 74 samples from cows with a history of various reproductive disorders and 197 samples from reproductively healthy cows. Medical history could not be obtained for 85 abattoir samples. Prior to sampling, minimum recommended size of the sample was calculated, using Win Episcope 2.0 software [16]. Announcement of the Statistical Office of the Republic of Serbia on the number of cattle [14] and expected prevalence of $17.3 \%$ [13] that would ensure a $95 \%$ confidence interval and produce an error of 5\% were used as input data for this calculation. Minimum recommended size of 220 animals was obtained. Therefore, a sample of 356 animals would not only provide an unbiased estimation of the prevalence of $N$. caninum-specific antibodies in the dairy cows of Vojvodina but would also reduce the error to $3.92 \%$.

Blood samples were obtained from 99 dogs during the 2008-2013 period, from various sources on several locations in Srem, Banat and Bačka (Figure 2). None of the sampled dogs, including six farm dogs, belonged to the same farms as cows from this study. All canine blood samples were collected from cephalic vein. The dogs were clinically examined prior to sampling and for each dog a record sheet, which included information on breed, gender, age, previous health problem and diet, was filled. For stray dogs, only gender and age (estimated by competent veterinarian) could be obtained.

Sample preparation procedure was identical for both cows and dogs: after being left to clot, blood was centrifuged
(3000 rpm for $10 \mathrm{~min}$ ) and separated sera were stored at $-20{ }^{\circ} \mathrm{C}$ until examination.

\section{Serological testing}

Two types of serological tests were used to detect $N$. caninum antibodies in cow sera. Initially 100 sera were assayed using the commercial competitive ELISA test kit (cELISA, VMRD Inc., Pullman, USA). The remainder 256 cow and all dog sera were examined with an indirect fluorescent antibody test (IFAT) using reagents marketed by VMRD. Both tests were performed according to the manufacturer's instructions. Cow sera, examined with ELISA, that presented inhibition percentages equal to or higher than $30 \%$ were considered positive. For IFAT, a recommended cut-off of 1:200 for cows and 1:50 for dogs was used. Dog sera that exhibited positive reaction at 1:50 were serially diluted until negativity was reached.

\section{Statistical analysis}

Seroprevalences and their confidence intervals, for both cows and dogs, were calculated using Quantitative Parasitology 3.0. [11]. For the statistical analysis of the possible effects of different factors (origin, farm type and history of reproductive disorders in cows and utilisation, breed, gender, age, origin and feeding habits in dogs) on the occurrence of anti$N$. caninum antibodies the chi-squared test was used at a significance level of $95 \%(p \leq 0.05)$. Where appropriate chi-squared test was replaced by Fisher's exact test or unconditional exact test. All these tests were computed using the above mentioned statistical software. Odds ratio (OR) was calculated using Win Episcope version 2.0 software [16]. Positive OR (OR > 1), 


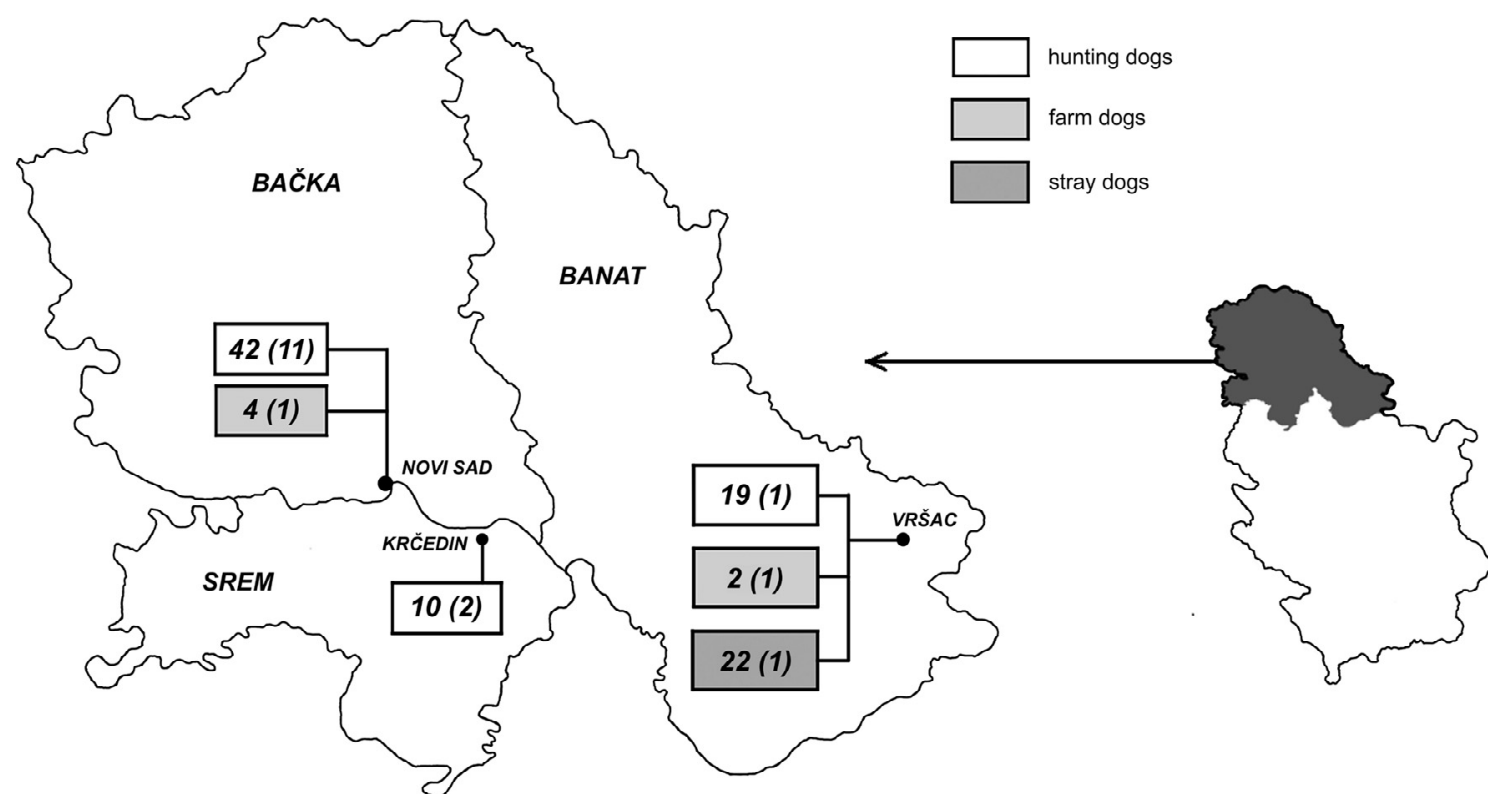

Figure 2. Geographical distribution of localities where blood samples were collected from hunting, farm and stray dogs. Numbers outside parentheses represent the dogs from the specific category that was tested on the given locality. Numbers between parentheses refer to the positive ones.

Table 1. Prevalence of seropositive cows according to the geographical origin, farm type and health status.

\begin{tabular}{|c|c|c|c|c|c|c|c|c|c|}
\hline & \multicolumn{3}{|c|}{ Examined } & \multicolumn{4}{|c|}{ Positive } & \multirow[b]{2}{*}{ CI $95(\%)$} & \multirow[b]{2}{*}{$p$-Value } \\
\hline & ELISA & IFAT & Total & ELISA & IFAT & Total & Rate $(\%)$ & & \\
\hline \multicolumn{10}{|l|}{ Geographical origin } \\
\hline Srem & 10 & 56 & 66 & 0 & 9 & 9 & 13.6 & $7.1-24.1$ & \multirow[t]{3}{*}{0.766} \\
\hline Banat & 31 & 78 & 109 & 3 & 16 & 19 & 17.4 & $11.4-25.6$ & \\
\hline Bačka & 59 & 122 & 181 & 4 & 23 & 27 & 14.9 & $10.3-20.9$ & \\
\hline \multicolumn{10}{|l|}{ Farm type } \\
\hline Commercial farms & 33 & 76 & 109 & 1 & 4 & 5 & 4.6 & $1.5-10.4$ & \multirow[t]{2}{*}{$0.0001^{\mathrm{a}}$} \\
\hline Smallholdings & 67 & 180 & 247 & 6 & 44 & 50 & 20.2 & $15.4-25.8$ & \\
\hline \multicolumn{10}{|c|}{ Reproductive disorders } \\
\hline Yes & 22 & 52 & 74 & 0 & 9 & 9 & 12.2 & $6.3-21.5$ & \multirow[t]{3}{*}{0.148} \\
\hline No & 0 & 197 & 197 & 0 & 37 & 37 & 18.8 & $13.9-24.8$ & \\
\hline nd & 78 & 7 & 85 & 7 & 2 & 9 & 10.6 & $5.5-19.2$ & \\
\hline Total & 100 & 256 & 356 & 7 & 48 & 55 & 15.4 & $12.0-19.6$ & \\
\hline
\end{tabular}

$\mathrm{nd}=$ No data regarding medical history could be obtained; ${ }^{\mathrm{a}}$ Difference between these prevalences was statistically significant $(p \leq 0.05)$.

with 95\% confidence interval (CI) that does not overlap with the null value of 1 and with $p \leq 0.05$, was considered statistically significant [15]. Confidence interval and $p$-value for OR were calculated using online MedCalc software version $12.6[8]$.

\section{Results}

Antibodies to $N$. caninum were found in $15.4 \%$ (55/356, CI 95\%:12.0-19.6) of cow sera. Seven positive sera were detected by ELISA and the remaining 48 by IFAT (Table 1). Among the risk factors evaluated, only cows originating from smallholdings had significantly greater odds $(\mathrm{OR}=5.28$, CI 95\%: 2.0-13.6, $p=0.0006$ ) of being seropositive in comparison to the group of farm cows.

$N$. caninum antibodies were found in $17.2 \%$ (17/99, CI 95\%: 10.8-26.2) of dogs, with titres of 50 in 15 dogs, 100 in two and 200 in one dog. Out of 17 seropositive animals, 14 (14/71, 19.7\%, CI 95\%: 11.2-30.9) came from the group of hunting dogs, one ( $1 / 22,4.5 \%$, CI $95 \%$ : $0.2-22.2)$ was a stray dog and two $(2 / 6,33.3 \%$, CI $95 \%$ : $6.3-72.9)$ belonged to a small group of farm dogs. Of all the risk factors evaluated statistical difference $(p=0.02)$ was observed in the occurrence of $N$. caninum-specific antibodies in dogs from Bačka versus dogs from Banat (Table 2). 
Table 2. Prevalence of anti-Neospora caninum antibodies in hunting, stray and farm dogs according to the breed, gender, age and region of origin.

\begin{tabular}{|c|c|c|c|c|c|c|c|c|c|c|c|c|}
\hline & \multicolumn{3}{|c|}{ Hunting } & \multicolumn{3}{|c|}{ Stray } & \multicolumn{3}{|c|}{ Farm } & \multicolumn{3}{|c|}{ Total } \\
\hline & $n$ & Positive & $\%$ & $n$ & Positive & $\%$ & $n$ & Positive & $\%$ & $n$ & Positive & $\%$ \\
\hline \multicolumn{13}{|l|}{ Breed } \\
\hline Purebreed & 66 & 14 & 21.2 & 0 & 0 & 0 & 2 & 1 & 50 & 68 & 15 & 22.1 \\
\hline Mongrel & 5 & 0 & 0 & 22 & 1 & 4.5 & 4 & 1 & 25 & 31 & 2 & 6.5 \\
\hline \multicolumn{13}{|l|}{ Gender } \\
\hline Female & 32 & 5 & 15.6 & 13 & 1 & 7.7 & 2 & 1 & 50 & 47 & 7 & 14.9 \\
\hline Male & 39 & 9 & 23.1 & 9 & 0 & 0 & 4 & 1 & 25 & 52 & 10 & 19.2 \\
\hline \multicolumn{13}{|l|}{ Age (years) } \\
\hline$\leq 1$ & 13 & 1 & 7.7 & 6 & 0 & 0 & 2 & 0 & 0 & 21 & 1 & 4.8 \\
\hline$>1, \leq 5$ & 45 & 11 & 24.4 & 13 & 1 & 7.7 & 4 & 2 & 50 & 62 & 14 & 22.6 \\
\hline$>5$ & 13 & 2 & 1.4 & 3 & 0 & 0 & 0 & 0 & 0 & 16 & 2 & 12.5 \\
\hline \multicolumn{13}{|l|}{ Origin } \\
\hline Srem & 10 & 2 & 20 & 0 & 0 & 0 & 0 & 0 & 0 & 10 & 2 & 20 \\
\hline Banat & 19 & 1 & 5.3 & 22 & 1 & 4.5 & 2 & 1 & 50 & 43 & 3 & 7 \\
\hline Bačka & 42 & 11 & 26.2 & 0 & 0 & 0 & 4 & 1 & 25 & 46 & 12 & $26.1^{\mathrm{a}}$ \\
\hline Total & 71 & 14 & 19.7 & 22 & 1 & 4.5 & 6 & 2 & 33.3 & 99 & 17 & 17.2 \\
\hline
\end{tabular}

$n=$ Number of examined dogs; $\%=$ prevalence; ${ }^{a}$ Difference between these prevalences was statistically significant $(p \leq 0.05)$.

In 42 hunting dogs with known feeding habits $11(26.2 \%$, CI 95\%: 14.9-41.6) were seropositive. No statistical differences $(p=0.4)$ were found between the dogs fed commercial food (2/12, 16.7\%, CI 95\%: 2.1-48.4), homemade food (8/22, $36.4 \%$, CI $95 \%$ : $17.2-59.3)$ and the mixture of two diets $(1 / 8,12.5 \%$, CI 95\%: 0.6-50.0).

Seropositive purebred dogs were present as follows: Dachshund $(n=1)$, English Springer Spaniel $(n=1)$, English Pointer $(n=1)$, German Shorthaired Pointer $(n=4)$, German Hunting Terrier $(n=1)$, Weimaraner $(n=1)$, Setter $(n=1)$, German Wirehaired Pointer $(n=2)$, Labrador Retriever $(n=1)$, Small Munsterlander Pointer $(n=1)$ and German Shepherd $(n=1)$.

Most (92 of 99) dogs were clinically normal and seven dogs had clinical signs which could not be related to neosporosis.

\section{Discussion}

The results of this study corroborate previous findings $[3,9$, $13,17]$ of $N$. caninum antibodies in both cattle and dogs from the territory of Vojvodina.

The prevalence of antibodies in dairy cattle from our study (15.4\%) was higher than the one found by Gavrilović et al. [3]. Similar to our study, their sample consisted of both aborting and randomly sampled cows, from both commercial and smallholding farms. Nevertheless, they found only $4.6 \%$ (23/500) of cows to be seropositive, which could be partly due to the small proportion of aborting cows in the total sample and the fact that they restricted their research to the south district of Banat. Different commercial tests were utilized in these studies (Gavrilovic et al. used ELISA manufactured by IDEXX and Svanova, while we used IFAT and ELISA manufactured by VMRD) which may have also influenced the results.
Vidić et al. [17] and Savović et al. [13] reported occurrence of $N$. caninum antibodies in $3.7 \%(5 / 132)$ and $17.3 \%(9 / 52)$ of dairy cows, respectively. Although small size of the study samples and the fact they consisted entirely of cows with reproductive disorders make these prevalences difficult to compare with, we referred to them in the interest of data transparency.

With regard to the risk factors, significant difference was observed between seroprevalences in cattle from commercial and from small farms in our study. Probable reason for these observations is the fact that biosecurity measures on commercial farms are generally superior to those on small family farms which are more likely to have dogs, the potential source of infection. Furthermore, cattle from smallholdings are usually associated with extensive production and often allowed to graze, which is, according to some authors [4, 10], one of the risk factors associated with seropositivity in cattle. Gavrilovic et al. [3] also observed that all cows from seropositive commercial farms in their study had access to the outdoor paddocks which resulted in higher herd prevalence in commercial farms (50.0\%), in comparison to smallholdings $(22.64 \%)$. On individual level, however, they found no significant difference between commercial (4.67\%) and small (4.50\%) farms.

Prevalence of $N$. caninum antibodies in dogs varies based on many factors, including age, origin and diet [1]. Pavičić et al. [9] were first to detect $N$. caninum antibodies in four out of $31(12.9 \%)$ dogs from Vojvodina. Examined dogs were mostly hounds, originating from Srem and Banat region. In the present study, we found antibodies in 17 out of 99 dogs (17.2\%). Samples were collected from all three regions of Vojvodina and higher prevalence was observed in dogs from Bačka (26.1\%) in comparison to dogs from Banat (7\%). Other factors, such as breed, age, diet or utilisation did not appear significant. However, since the sample size was relatively small 
and samples originated from various sources and were collected over several years, no definitive conclusion can be made. Nevertheless, we recorded findings for the benefit of future studies.

Presently, there are no reports of confirmed clinical neosporosis in any host in Serbia, including cattle and dogs.

In conclusion, our study confirmed the presence of $N$. caninum antibodies in general population of dairy cows in Vojvodina, with a higher prevalence detected in animals originating from smallholding farms. Specific antibodies against $N$. caninum were also found in dogs from the same province, with slightly higher prevalence observed in dogs from Bačka.

Acknowledgements. To the Ministry of Education, Science and Technological Development of the Republic of Serbia which supported this study with Grants No. TR31034 (PhD grant for Ljiljana Kuruca) and No. TR31084.

\section{References}

1. Dubey JP, Schares G, Ortega-Mora LM. 2007. Epidemiology and control of neosporosis and Neospora caninum. Clinical Microbiology Reviews, 20, 323-367.

2. Dubey JP, Schares G. 2011. Neosporosis in animals - the last five years. Veterinary Parasitology, 180, 90-108.

3. Gavrilović P, Živulj A, Todorović I, Jovanović M, Parunović J. 2013. Investigation of importance of Neospora caninum in aetiology of abortion in dairy cows in Serbia. Revue de Médecine Vétérinaire, 164, 100-104.

4. Guimarães JS Jr, Souza SLP, Bergamaschi DP, Gennari SM. 2004. Prevalence of Neospora caninum antibodies and factors associated with their presence in dairy cattle of the north of Paraná state, Brazil. Veterinary Parasitology, 124, 1-8.

5. Lalošević V, Lalošević D, Čapo I, Simin V, Galfi A, Traversa D. 2013. High infection rate of zoonotic Eucoleus aerophilus infection in foxes from Serbia. Parasite, 20, 3.

6. McAllister MM, Dubey JP, Lindsay DS, Jolley WR, Wills RA, McGuire AM. 1998. Dogs are definitive hosts of Neospora caninum. International Journal for Parasitology, 28, 1473-1478.
7. McInnes LM, Irwin P, Palmer DG, Ryan UM. 2006. In vitro isolation and characterisation of the first canine Neospora caninum isolate in Australia. Veterinary Parasitology, 137, 355363.

8. MedCalc statistical software 12.6.0 (online version, www. medcalc.org/calc/odds_ratio.php), Ostend, Belgium (accessed 25 August 2013).

9. Lj Pavičić, Lalošević V, Lj Spasojević-Kosić, Lauš S, Simin S. 2011. Seroprevalence of Neospora caninum in dogs. Contemporary Agriculture, 61, 453-458.

10. Rinaldi L, Fusco G, Musella V, Veneziano V, Guarino A, Taddei R, Cringoli G. 2005. Neospora caninum in pastured cattle: determination of climatic, environmental, farm management and individual animal risk factors using remote sensing and geographical information systems. Veterinary Parasitology, 128, 219-230.

11. Rozsa L, Reiczigel J, Majoros G. 2000. Quantifying parasites in samples of hosts. Journal of Parasitology, 86, 228-232.

12. Ruehlmann D, Podell M, Oglesbee M, Dubey JP. 1995. Canine neosporosis: a case report and literature review. Journal of the American Animal Hospital Association, 31, 174-183.

13. Savović M, Lalošević V, Simin S, Pavičić LJ, Boboš S. 2012. Seroprevalence of Neospora caninum in dairy cows with reproductive disorders in Vojvodina province, Serbia. Lucrări Ştiintifice Medicină Veterinară, 45, 161-166.

14. Statistical Office of the Republic of Serbia, Statistics of Agriculture, Announcement No. 036 released on 21.02.2012, http://webrzs.stat.gov.rs/WebSite/repository/documents/00/00/ 58/98/po12122011.pdf (accessed 14 May 2013).

15. Szumilas M. 2010. Explaining Odds ratio. Journal of the Canadian Academy of Child and Adolescent Psychiatry, 19, 227-229.

16. Thrusfield M, Ortega C, de Blas I, Noordhuizen JP, Frankena K. 2001. Win Episcope 2.0: improved epidemiological software for veterinary medicine. Veterinary Record, 148, 567-572.

17. Vidić B, Grgić Ž, Savić S, Bugarski D. 2011. Neospora caninum causes abortions in cows, Scientific Symposium "Reproduction of domestic animals", Naučna KMD, Belgrade, Divčibare, Serbia.

Cite this article as: Kuruca L, Spasojević-Kosić L, Simin S, Savović M, Lauš S \& Lalošević V: Neospora caninum antibodies in dairy cows and domestic dogs from Vojvodina, Serbia. Parasite, 2013, 20, 40.

\section{PARASTE}

An international open-access, peer-reviewed, online journal publishing high quality papers on all aspects of human and animal parasitology

Reviews, articles and short notes may be submitted. Fields include, but are not limited to: general, medical and veterinary parasitology; morphology, including ultrastructure; parasite systematics, including entomology, acarology, helminthology and protistology, and molecular analyses; molecular biology and biochemistry; immunology of parasitic diseases; host-parasite relationships; ecology and life history of parasites; epidemiology; therapeutics; new diagnostic tools.

All papers in Parasite are published in English. Manuscripts should have a broad interest and must not have been published or submitted elsewhere. No limit is imposed on the length of manuscripts.

Parasite (open-access) continues Parasite (print and online editions, 1994-2012) and Annales de Parasitologie Humaine et Comparée (1923-1993) and is the official journal of the Société Française de Parasitologie. 